of all such issues: while the reader may himself be willing to work as a mere $\operatorname{cog}$ in the library wheel, the cultured student prefers to make the library merely an auxiliary in his own development.

\section{NEW ZEALAND AND THE RECENT ERUPTION.}

NEW ZEALAND forms one link of the great volcanic chain that girdles the Pacific Ocean, from South Shetland and Cape Horn up through the Andes, Mexico, British Columbia, and Alaska, crossing into Asia through the Aleutian Islands, and stretching south through the Kurile Islands, Japan, Ladrone Islands, Philippines, and West Indies, to Mounts Erebus and Terror, in the antarctic zone. The greatest volcanic energy is found where this great girdle crosses the torrid zone, - in the northern Andes, Central America, and Mexico, to the east; and in the Philippines and West Indies, to the west. Here the great stresses and pressures caused by the slow cooling. and contraction of the crust of the earth are perhaps increased by others due to the centrifugal force of its rapid rotation on its axis. New Zealand lies a thousand miles south-east of Australia, in latitude $40^{\circ}$ south, longitude $175^{\circ}$ east, the antipodes of Spain, and comprises two large islands (North Island and South Island), with numberless smaller ones around their shores, an area, in all, of about 100,000 square miles, or nearly that of Great Britain and Ireland.

The accompanying physical map of the islands will indicate at a glance the general topographic features. The centre of North Island is occupied by lofty mountains, which send off spurs in various directions to the coast, and are covered with forests from their bases nearly to their summits. The north-western peninsula abounds in fertile and well-watered valleys, and the main body of the island is characterized by gently sloping hilly ranges and low-lying tablelands, varied here and there by volcanic peaks, and covered with a luxuriant growth of timber. In the south centre is a wild highland region, seldom visited by travellers.

South Island is very different. The snowy peaks of the great southern Alps stretch along its western side, from ten to thirteen thousand feet in height, densely wooded to the snow-line. To the west are vast snow-fields and glaciers; and the coast is deeply and sharply indented by bays and fiords, which, with the numerous lakes of glacial origin, remind one strongly of the coast of Norway, although $30^{\circ}$ nearer the equator. A low range lies along the centre of the island, with spurs at right angles, and numerous ravines through which the rivers break their way to the south-east. Farther east are terraces and plairs.

North Island, the scene of the recent eruption, is somewhat smaller than South Island, and is about the size of Cuba, though stretching r.orth and south, instead of east and west. The lake district, or region in the north-east centre of the island, has been well called the wonderland of the world, and for magnificent scenery and wonderful derelopment of geysers, fumaroles, and hot springs, comes second only to our own Yellowstone park, if indeed it be not its peer. In the volcanic district, stretching from Mount Egmont. the westem promontory, north-eastward throug'. the centre of the island to White Island in ti.e Bay of Plenty, there have been hitherto but tro active volcanoes, - Tongariro (6,500 feet), a pjak 30 miles south of Lake Taupo; and Wakari 860 feet), on White Island. The great snow-carped dome of Ruapehu, just south of Tongariro, and the highest point in the island $(9,190$ font); Mount Egmont (8,200 feet), and the great volcanic promontory on which it stands; and hundreds of other extinct craters and vast fields of lava, tufa, and scoriae, - these all bear witness to the energy of volcanic action in comparatively recent time. And yet there has been no serious eruption till row, within the memory of European settlers, and even the Maori traditions give no account of one. Earthquakes, however, are not uncommon, though seldom sufficiently severe to cause great destruction, Cook Strait being regarded as the centre of the region generally disturbed: 342 were recorded from 1869 to 1879 , and 28 in 1882 , only one of which was at all severe, while ten were described as 'smart,' and the other seventeen only slight tremors. The most severe shock of which there is any record occurred the evening of Jan. 23, 1855, and caused great destruction in Wellington. Many fissures in the earth, landslides, and a great sea-wave were caused, and minor shocks followed it at decreasing intervals for about three months. There are many evidences that a gradual elevation of the whole country is going on ; as, for instance, rocks are now visible in Cook Strait where there were none when the country was first discovered. This indicates that earthquakes or other disturbances are likely to occur, and helps us to understand the late eruption.

Lake Taupo, the great lake in the centre of the island, 1,250 feet above sea-level, 30 miles long, and 20 broad, covering an area of 250 square miles, occupies a depression caused by some great eruption, and is surrounded by cliffs of lava a thousand feet in height, with a little extinct crater 

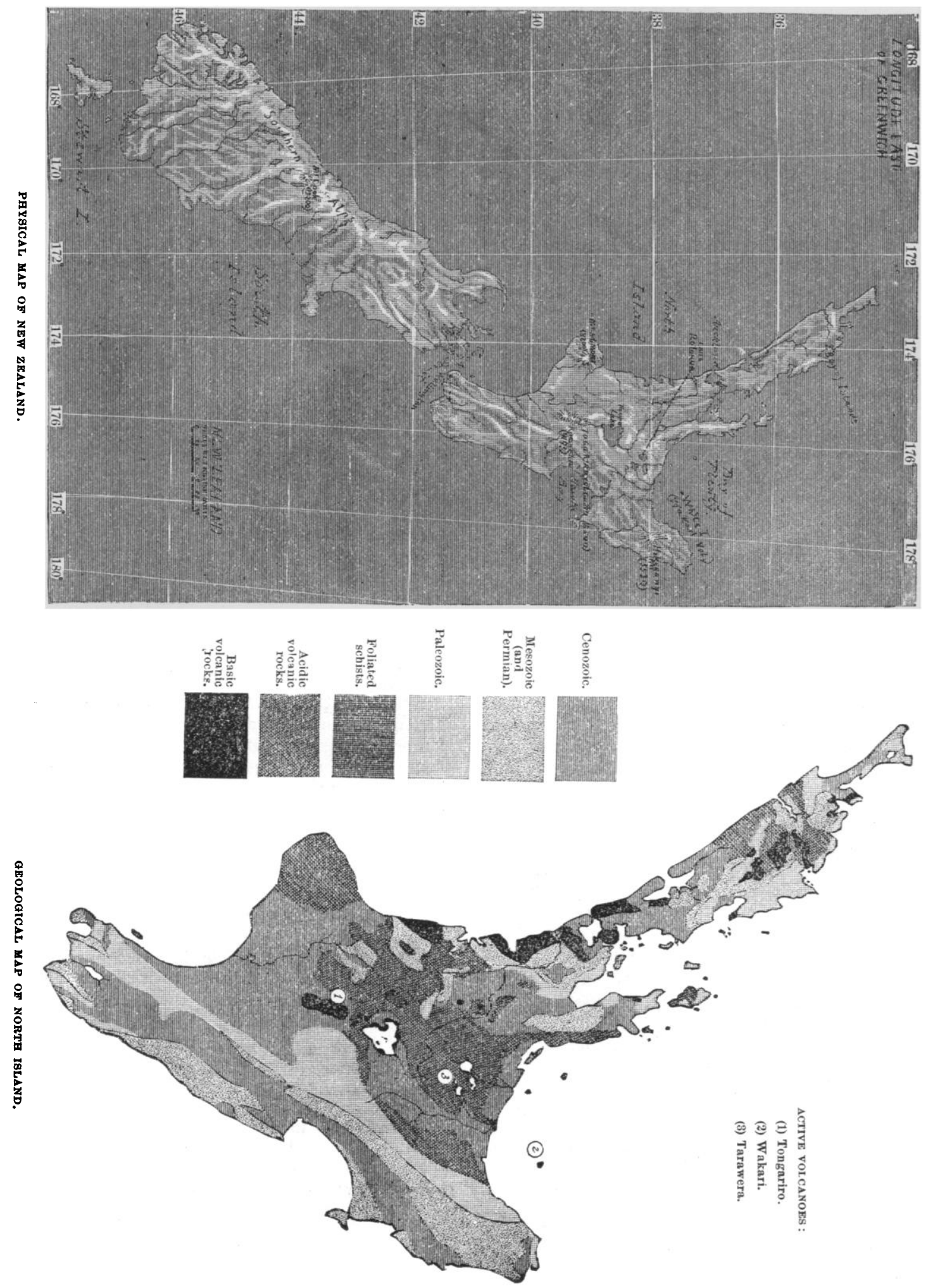
on an island in its centre - like Crater Lake, in Oregon, though on a larger scale. Out of it flows the Waikato River, running 200 miles northerly and westerly; and along its banks, some 25 miles from the lake, is one of the two great geyser districts of the island. The other and more extensive district is 40 miles north-north-east of Lake Taupo, and about the same distance from the shores of the Bay of Plenty. Here, among the mountains, lakes, and forests of the famous lake district of New Zealand, are the celebrated geysers, hot springs, mud volcanoes, and solfataras, which rank next to those of the Yellowstone in interest, and even surpass those of Iceland. Of the lakes the most picturesque is Tarawera, surrounded by rugged bluffs, with the mountain-peak of the same name close by, to the eastward. Next in size is Lake Rotorua, 6 miles in diameter, with a little extinct volcanic cone in the centre. Rotomahana, or Warm Lake, is surrounded by boiling springs and siliceous terraces, and the temperature of the whole body of water is always as high as $90^{\circ} \mathrm{F}$.

It was here, then, in the lovely lake district, and from the ' not dead but sleeping' peak of Tarawera, that the great eruption burst forth on June 10, an eruption unprecedented in the history or traditions of the island, though far surpassed by others that have left their ineffaceable record in the rocks. Two years ago, it is said, the water of Lake Ratakakahi, usually cold, grew hot; and there was a strong outflow down the Wairoa valley into Lake Tarawera for a day, when it resumed its normal condition. This was all the warning, so far as yet known, of this awful convulsion. At 1 A. M., the inhabitants of the little village of Wairoa were aroused by a violent shaking of the earth. followed by a continuous but not unpleasant motion. A bright red glow became visible about the top of the mountain, and vivid flashes of light seemed to shoot up into the air. In an hour the flashes of light became what seemed a massive pillar of fire, rising, increasing, and extending along the range. A dull rumbling accompanied it, and became a terrific roar, with continuous explosions, loud thunder, and vivid lightning, till heaven and earth seemed to be torn asunder. The air was filled with sulphurous odors, falling stones, mud, and lava. The village was annihilated, more than a hundred natives perished, and the fertile plains were buried in mud and ashes.

Such, briefly, are the first particulars that have reached us of this terrible convulsion. It has indeed given a temporary check to the progress of the island. But the mountain is now said to be quiet again, and perhaps not many years will have passed before the catastrophe is forgotten and its damages repaired, as has been so often the case with Vesuvius and Etna. Geology teaches that this is an old and dying region of volcanic energy, and that each eruption is less violent than the one preceding. We may therefore hope that this paroxysm will give relief, until the tension of the earth's crust, accumulated for another decade of centuries, shall again burst its bonds.

EveretT HAYDEN.

\section{THE AMERICAN LIBRARY ASSOCIATION.}

THE ninth general meeting of this association was convened at Milwaukee, Wis., on Wednesday, the rth of July, and was dissolved on Saturday of the same week. Dr. W. F. Poole, president of the association, and librarian of the Chicago public library, presided at all the sessions, of which the first were mainly devoted to the reports of committees, and the address of the president, which was brief and pertinent. Dr. Poole dwelt on the present urgent needs of libraries in general, and regarded it as a great misfortune that the plans for a building for the library of congress, presented to the association at its Washington meeting in 1881 and condemned by the unanimous voice of its members, and also the year following at Cincinnati, should have been definitely adopted by congress. The committee on the American library association catalogue reported progress in the work of formation of a catalogue of the works most suitable for the foundation of public libraries. The programme of the meeting was one of unusual interest, embracing about twentyfive papers relating in large part to special points in library management, though by no means wholly so. For example: Mr. Richardson's (Library Hartford theological seminary) paper, 'Why librarians know,' showed a very good basis for his modest plea for the recognition of librarianship as one of the learned professions. Whether they profess it or not, at all events librarians practise learning, and they have to do so, or they couldn't be librarians. The librarians of the new era are a long way from exemplifying the common insinuation that their knowledge relates rather to the outside of books than to their contents. Among librarians the number of bookproducers is very large. Mr. Charles A. Cutter (Boston athenaeum) followed with a brief paper on 'Close classification,'- a problem which, more perhaps than any other, is agitating the librarians of to-day. Shall the library be divided into a few broad classes, - history, geography, science, art, literature, and the like : or shall these be broken into smaller parts, setting the history of England, Germany, France, etc., each by itself, and breaking up science into physics, botany, zoölogy, etc. ; 